\title{
Fine particle characterization in a coastal city in China: composition, sources, and impacts of industrial emissions
}

\author{
Lu Lei ${ }^{1,2}$, Conghui Xie ${ }^{1,2}$, Dawei Wang ${ }^{1}$, Yao He ${ }^{1,2}$, Qingqing Wang ${ }^{1,2}$, Wei Zhou ${ }^{1,2}$, Wei Hu ${ }^{3}$, Pingqing Fu ${ }^{2,3}$, \\ Yong Chen ${ }^{1}$, Xiaole Pan ${ }^{1,2}$, Zifa Wang ${ }^{1,2}$, Douglas R. Worsnop ${ }^{4}$, and Yele Sun ${ }^{1,2}$ \\ ${ }^{1}$ State Key Laboratory of Atmospheric Boundary Layer Physics and Atmospheric Chemistry, \\ Institute of Atmospheric Physics, Chinese Academy of Sciences, Beijing 100029, China \\ ${ }^{2}$ College of Earth and Planetary Sciences, University of Chinese Academy of Sciences, Beijing 100049, China \\ ${ }^{3}$ Institute of Surface-Earth System Science, Tianjin University, Tianjin 300072, China \\ ${ }^{4}$ Aerodyne Research Inc., Billerica, Massachusetts 01821, USA
}

Correspondence: Yele Sun (sunyele@ mail.iap.ac.cn)

Received: 21 September 2019 - Discussion started: 7 October 2019

Revised: 31 December 2019 - Accepted: 11 February 2020 - Published: 9 March 2020

\begin{abstract}
Aerosol composition and sources have been extensively studied in developed regions in China. However, aerosol chemistry in coastal regions of eastern China with high industrial emissions remains poorly characterized. Here we present a comprehensive characterization of aerosol composition and sources near two large steel plants in a coastal city in Shandong in fall and spring using a $\mathrm{PM}_{2.5}$ timeof-flight aerosol chemical speciation monitor. The average $( \pm 1 \sigma)$ mass concentration of $\mathrm{PM}_{2.5}$ in spring $2019(54 \pm$ $\left.44 \mu \mathrm{g} \mathrm{m}^{-3}\right)$ was approximately twice that $\left(26 \pm 23 \mu \mathrm{g} \mathrm{m}^{-3}\right)$ in fall 2018. Aerosol composition was substantially different between the two seasons. While organics accounted for $\sim 30 \%$ of the total $\mathrm{PM}_{2.5}$ mass in both seasons, sulfate showed a considerable decrease from $28 \%$ in September to $16 \%$ in March, which was associated with a large increase in nitrate contribution from $17 \%$ to $32 \%$. Positive matrix factorization analysis showed that secondary organic aerosol (SOA) dominated the total OA in both seasons, accounting on average for $92 \%$ and $86 \%$, respectively, while the contribution of traffic-related hydrocarbon-like OA was comparable ( $8 \%-9 \%$ ). During this study, we observed significant impacts of steel plant emissions on aerosol chemistry nearby. The results showed that aerosol particles emitted from the steel plants were overwhelmingly dominated by ammonium sulfate and/or ammonium bisulfate with the peak concentration reaching as high as $224 \mu \mathrm{g} \mathrm{m}^{-3}$. Further analysis showed similar mass ratios for $\mathrm{NO}_{x} / \mathrm{CO}(0.014)$ and $\mathrm{NO}_{x} / \mathrm{SO}_{2}$ (1.24) from the two different steel plants, which
\end{abstract}

were largely different from those during periods in the absence of industrial plumes. Bivariate polar plot analysis also supported the dominant source region of ammonium sulfate, $\mathrm{CO}$, and $\mathrm{SO}_{2}$ from the southwest steel plants. Our results might have significant implications for better quantification of industrial emissions using ammonium sulfate and the ratios of gaseous species as tracers in industrial regions and nearby in the future.

\section{Introduction}

Atmospheric fine particles $\left(\mathrm{PM}_{2.5}\right.$, particles with an aerodynamic diameter less than $2.5 \mu \mathrm{m}$ ) have great impacts on visibility (Reddy and Venkataraman, 2000; Jinhuan and Liquan, 2000), climate forcing (Lohmann and Feichter, 2005; Carslaw et al., 2010), and human health (Laden et al., 2000; Pope III et al., 2002). Among the sources of aerosol particles, industrial emissions have become one of the most important sources in rapidly developing countries, e.g., China (Cao et al., 2011; Huang et al., 2014). However, previous studies on chemical composition and sources were mostly conducted in densely populated urban environments and remote or rural areas (Allan et al., 2010; Aiken et al., 2009; Sun et al., 2012), while industrial plumes that can have a large impact on urban air quality and residents nearby are much less characterized. Aerosol particles in regions under the influences of industrial emissions contain much higher concentrations of 
toxic substances than those observed at urban and rural areas (Osornio-Vargas et al., 2003; Lage et al., 2014), leading to much higher health risks for people living nearby. Therefore, it is critically important to characterize the chemical composition and sources of fine particles in the vicinity of industrial plants and to have a better understanding of their formation mechanisms, evolution processes, and potential health effects (Davidson et al., 2005).

Industrial activities in steelmaking such as coke production and ore sintering emit a large amount of gaseous species, e.g., $\mathrm{SO}_{2}, \mathrm{NO}_{x}, \mathrm{CO}$ (Brock et al., 2003; Weitkamp et al., 2005), and particulate matter (Almeida et al., 2015; Taiwo et al., 2014). Heavy metals, including Fe, Mn, Pb, etc. (Wong et al., 2006; Yang et al., 2018); specific polycyclic aromatic hydrocarbons (PAHs) (Athanasios et al., 2011; Leoni et al., 2016); secondary inorganic species (Setyan and Jing, 2017; Wu et al., 2018); and OC/EC (organic carbon to elemental carbon ratio) (Chow et al., 2011) have been used as tracers to identify various industrial processes and to estimate their influences on air quality. During the last decade, real-time measurement instruments, e.g., the aerosol time-of-flight mass spectrometer (ATOFMS) and the Aerodyne aerosol mass spectrometer (AMS), have been used to measure the rapid changes in particle mixing states and chemical composition of industrial particles (Dall'Osto et al., 2008; Setyan et al., 2019). Dall'Osto et al. (2008) found several unique types of particles such as Fe-rich, Pb-rich, Zn-rich, and Ni-rich particles from steelmaking progresses, and Setyan et al. (2019) found a large increase in nonrefractory chloride from the $\mathrm{Fe}-$ Mn plant and the adjacent steelworks based on the measurements of a high-resolution time-of-flight AMS. Although the real-time measurements of fine particles are important for understanding the rapid evolutionary processes of aerosol composition, size distributions, and mixing states from industrial plumes, few studies have been conducted in highly industrialized areas in China.

Rizhao, located to the west of Yellow Sea, is one of the most important steel production bases in Shandong, China. The steel production in 2018 was approximately $26 \times 10^{6} \mathrm{t}$, which is $\sim 40 \%$ of the total production in Shandong. In addition to emissions from the steel plants, the air pollution in Rizhao is subject to multiple influences from local emissions, regional transport from Linyi to the west and Weifang to the northwest, and sea-land breezes. According to the Environment Statement of Shandong province, the air quality in Rizhao has improved significantly with the annual average $\mathrm{PM}_{2.5}$ decreasing from $\sim 70 \mu \mathrm{g} \mathrm{m}^{-3}$ in 2013 to $\sim 50 \mu \mathrm{g} \mathrm{m}^{-3}$ in 2017. However, the $\mathrm{PM}_{2.5}$ still exceeds the National Ambient Air Quality Standard ( $35 \mathrm{~g} \mathrm{~m}^{-3}$ as an annual average) by more than $40 \%$, and severe haze episodes were also frequently observed in winter. Although aerosol composition, sources, and formation mechanisms have been widely characterized in Beijing-Tianjin-Hebei, the Yangtze River Delta, and the Pearl River Delta during the last decade (Li et al., 2017), aerosol chemistry in the coastal city of Rizhao, and chemical characteristics of steel plant emissions, are rarely characterized. Therefore, it is of importance to investigate the composition, sources, and variations in aerosol particles near industrial areas and to better understand their impacts on urban air quality and human health.

In this work, we conducted two campaigns in the vicinity of steel plants in Rizhao in September 2018 and March 2019 using an Aerodyne time-of-flight aerosol chemical speciation monitor (ToF-ACSM) that was equipped with a $\mathrm{PM}_{2.5}$ aerodynamic lens and a capture vaporizer. Aerosol particle composition, diurnal variations, and potential sources are characterized, and the sources of organic aerosol are analyzed with positive matrix factorization. In particular, the chemical characteristics of pollutants from the emissions of steel plants, and their impacts on air quality, are elucidated.

\section{Experimental methods}

\subsection{Sampling site and measurements}

All measurements were carried out at a site near two steel plants in the coastal city of Rizhao, Shandong $\left(35^{\circ} 10^{\prime} 59^{\prime \prime} \mathrm{N}\right.$, $119^{\circ} 23^{\prime} 57^{\prime \prime} \mathrm{E}$ ), from 2 to 29 September 2018 and 2 to 29 March 2019. As shown in Fig. 1, the sampling site is located approximately $2 \mathrm{~km}$ northeast of the Rizhao steel plant (RSP), $1 \mathrm{~km}$ southwest of the Shandong steel plant (SSP), and $\sim 1 \mathrm{~km}$ from the Yellow Sea. As shown in Fig. 1c and $\mathrm{d}$, the prevailing winds were from the east and southeast during daytime in both September and March, while they were dominantly from the north in September and from the west in March during nighttime. As a result, the sampling site was subject to significant influence from sea-land breeze. Also note that the two steel plants have differences in technologies for controlling the emissions of pollutants. The newly built SSP uses more advanced purification and emission control technologies, e.g., dry desulfurization technology with the advanced activated coke compared with wet limestonegypsum flue-gas desulfurization (FGD) used in RSP. According to the National Bureau of Statistics of China, the annual steel production of the RSP was $\sim 18 \times 10^{6} \mathrm{t}$ and that of the SSP was $\sim 8 \times 10^{6} \mathrm{t}$.

An Aerodyne ToF-ACSM, which is equipped with a $\mathrm{PM}_{2.5}$ aerodynamic lens and a capture vaporizer (CV), was deployed for real-time measurements of non-refractory aerosol species in fine particles $\left(\mathrm{NR}-\mathrm{PM}_{2.5}\right)$, including organics (Org), sulfate $\left(\mathrm{SO}_{4}\right)$, nitrate $\left(\mathrm{NO}_{3}\right)$, ammonium $\left(\mathrm{NH}_{4}\right)$, and chloride $(\mathrm{Chl})$ at a time resolution of $2 \mathrm{~min}$. Briefly, ambient aerosol particles were first drawn into the sampling line at a flow rate of $\sim 3 \mathrm{~L} \mathrm{~min}^{-1}$ after passing through a $\mathrm{PM}_{2.5}$ cyclone (URG-2000-30EH). Aerosol particles were then dried with a Nafion dryer and sampled into the ToF-ACSM at a flow rate of $\sim 0.1 \mathrm{~L} \mathrm{~min}^{-1}$. After focusing into a narrow particle beam and flying through the vacuum chamber, nonrefractory aerosol species were flash vaporized at $\sim 540^{\circ} \mathrm{C}$ 
(a)

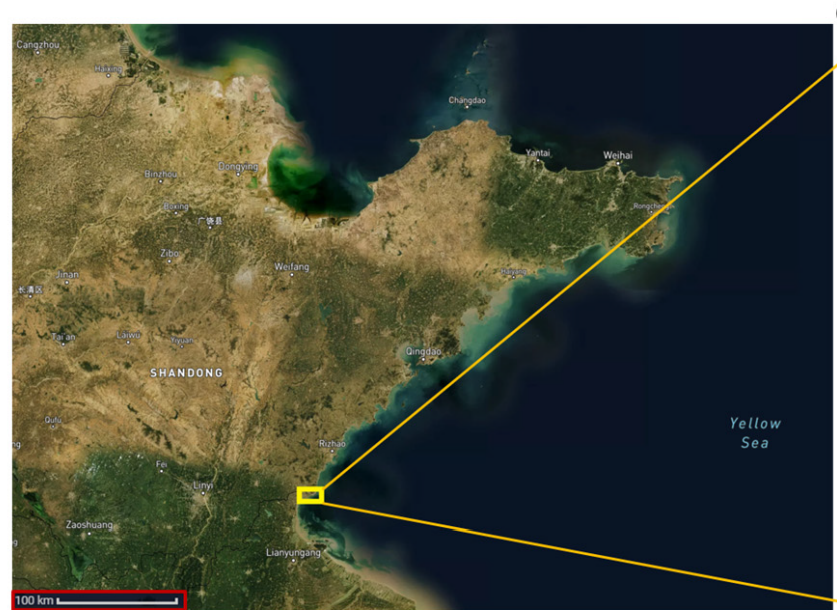

(c)

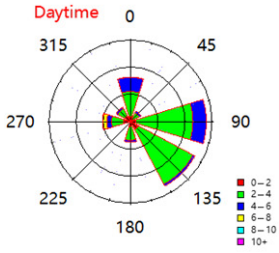

(b)

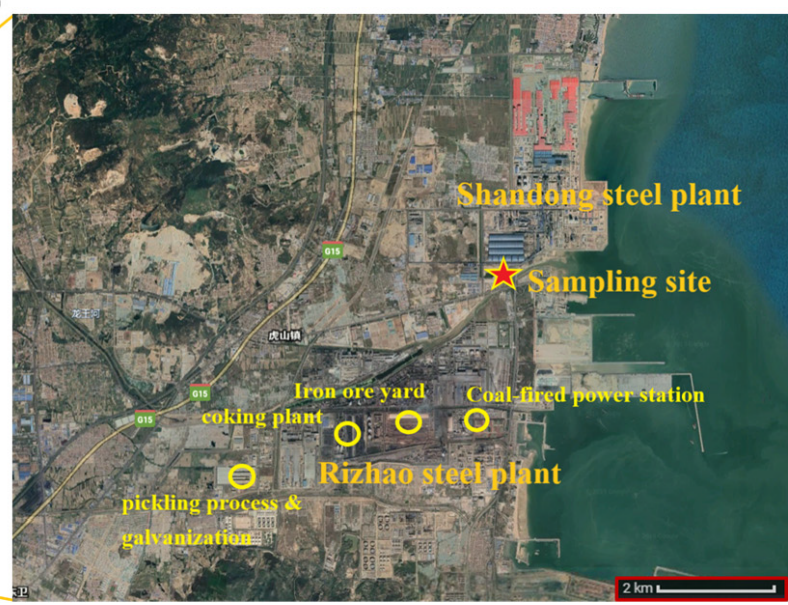

(d)

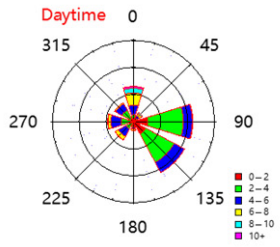

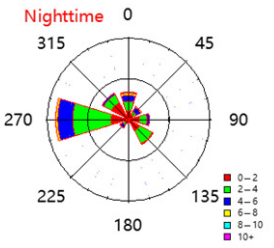

Figure 1. (a, b) Location of the sampling site ( $\odot$ Google Earth). Panels (c) and (d) show wind rose plots of daytime and nighttime for the entire study in September 2018 and March 2019, respectively.

and then ionized immediately by the $70 \mathrm{eV}$ electron impact. The ions were analyzed using the time-of-flight mass analyzer and detected by an SGE dynode detector (Fröhlich et al., 2013). Similar to quadrupole-ACSM (Ng et al., 2011b), the mass concentrations of aerosol species were derived from the differences between sampling mode and filter mode. The ionization efficiency (IE) and relative ionization efficiencies (RIEs) were calibrated using pure $\mathrm{NH}_{4} \mathrm{NO}_{3}$ and $\left(\mathrm{NH}_{4}\right)_{2} \mathrm{SO}_{4}$ before and after the campaigns. The RIE of sulfate was fairly robust (1.1), while that of ammonium changed from 3.1 in September 2018 to 3.8 in March 2019. The default RIE values of 1.1, 1.4, and 1.3 were used for nitrate, organics, and chloride, respectively.

In addition to NR-PM 2.5 aerosol species, a sevenwavelength Aethalometer (model AE33, Magee Scientific) was used to measure black carbon (BC) at a time resolution of $1 \mathrm{~min}$. The gaseous species including $\mathrm{SO}_{2}$ (model 43i), $\mathrm{CO}$ (model 48i), and $\mathrm{NO}_{x}$ (model 42i) were measured by various gas analyzers from Thermo Fisher Scientific, and the meteorological parameters including temperature $(T)$, relative humidity (RH), wind speed (WS), and wind direction (WD) were measured by a WS500-UMB smart weather sensor (Lufft).

\subsection{Data analysis}

The mass concentration and chemical composition were analyzed using the standard ToF-ACSM data analysis software (Igor-based Tofware_2_5_13_ACSM; https://www.tofwerk. com/tofware, last access: 20 July 2019). A collection efficiency (CE) of $\sim 1$ was used for mass quantifications as indicated by previous studies that AMS or ACSM with CV has a fairly robust $\mathrm{CE}$ of $\sim 1$ (Hu et al., 2016a, 2018a, b). Our results showed that NR-PM $2.5+\mathrm{BC}$ was well correlated with the total $\mathrm{PM}_{2.5}$ mass in both spring and fall $\left(r^{2}=0.54\right.$ and 0.86 ), and the regression slopes of 0.89 and 0.78 suggested that the mass quantification of the ToF-ACSM was reasonable, considering that mineral dust was not measured in this study.

The bilinear model positive matrix factorization (PMF) (Paatero and Tapper, 2010) has been widely used to deconvolve organic aerosol (OA) into different factors (Lanz et al., 2007; Ulbrich et al., 2009; Sun et al., 2011). In this study, PMF analysis was performed for the organic mass spectra from ToF-ACSM measurements to determine the potential OA from different sources and processes. The detailed procedures for pretreatment of the data and error matrices were presented in Zhang et al. (2011). Considering the limited sensitivity of the ToF-ACSM, $m / z$ 's larger than 120 and 180 were excluded in PMF analysis in September 2018 and March 2019, respectively, due to their low signal-to-noise ratios and low contributions to the total OA mass. After careful evaluations of mass spectral profiles, diurnal variations, and correlations with external tracers, three OA factors including a hydrocarbon-like OA (HOA), a less oxidized oxygenated OA (LO-OOA), and a more oxidized OOA (MOOOA) were determined in September 2018, and four factors, 
i.e., HOA, LO-OOA, MO-OOA, and a coal combustion OA (CCOA), were identified in March 2019. Compared with previous OA factors identified from PMF-AMS analysis ( $\mathrm{Ng}$ et al., 2011a), the mass spectra of both primary and secondary OA factors showed much higher $f_{44}$ (fraction of $m / z 44$ in $\mathrm{OA})$ in this study due to increased thermal decomposition on the surface of CV (Hu et al., 2018a, b). Hu et al. (2018a) also found that the previous AMS tracer $m / z$ 's are still present and usable in mass spectra although the fragmentation in $\mathrm{CV}$ tends to shift towards small $m / z$ 's due to additional thermal decomposition. Comparisons of PMF results further showed consistent time series of OA factors between $\mathrm{CV}$ and standard vaporizer (SV), yet the CV may introduce higher uncertainty in separating different types of OOA (Hu et al., 2018b).

\section{Results and discussion}

\subsection{Mass concentrations, chemical composition, and diurnal variations}

Figure 2 shows the time series of aerosol species, gaseous species, and meteorological parameters during the two seasons. The average $( \pm \sigma) \mathrm{RH}$ and $T$ was $62 \%( \pm 15 \%)$ and $23^{\circ} \mathrm{C}\left( \pm 3{ }^{\circ} \mathrm{C}\right)$ in September 2018 , which were overall higher than those $\left(60 \pm 4 \%\right.$ and $10 \pm 4^{\circ} \mathrm{C}$, respectively) in March 2019, while the average WS was comparable between the two seasons $\left(2.8 \pm 1.1 \mathrm{~m} \mathrm{~s}^{-1}\right.$ vs. $\left.3.2 \pm 1.9 \mathrm{~m} \mathrm{~s}^{-1}\right)$. One of the major differences in meteorological conditions is wind direction. While the prevailing winds were both from the east and southeast during daytime, they were mainly from the north in September and the west in March at night. We also noticed a considerable frequency of southwesterly winds in spring of 2019, suggesting a high potential impact of RSP on the sampling site.

The average $\mathrm{PM}_{2.5}\left(\mathrm{NR}-\mathrm{PM}_{2.5}+\mathrm{BC}\right)$ concentration was $\sim 26 \pm 23 \mu \mathrm{g} \mathrm{m}^{-3}$ for the entire study in September 2018, which was approximately half of that $\left(54 \pm 44 \mu \mathrm{g} \mathrm{m}^{-3}\right)$ in March 2019. This result suggested that air quality in March was much worse than that in September, and the PM loading was even more than 50\% higher than the National Ambient Air Quality Standard ( $35 \mu \mathrm{g} \mathrm{m}^{-3}$ as an annual average). According to the measurements at the Environmental Monitoring Station of Rizhao, the average $\mathrm{PM}_{2.5}$ mass concentration in September showed a continuous decrease from $50 \mu \mathrm{g} \mathrm{m}^{-3}$ in 2013 to $22 \mu \mathrm{g} \mathrm{m}^{-3}$ in 2018 , suggesting a significant improvement in air quality in September. However, the $\mathrm{PM}_{2.5}$ mass concentration remained at relatively high levels ranging from 54 to $78 \mathrm{\mu g} \mathrm{m}^{-3}$ in March during the years of 20132018 , indicating a great challenge in reducing PM in this season.

Figure 2 shows the average aerosol composition during fall and spring. While organics consisted of approximately onethird of the total $\mathrm{PM}_{2.5}$ mass in both spring and fall, large differences in secondary inorganic species were observed.
For example, sulfate was the second largest component in $\mathrm{PM}_{2.5}$ in fall, accounting for $28 \%$, and its contribution decreased to $16 \%$ in spring. In contrast, nitrate showed largely elevated contributions from $17 \%$ to $32 \%$. These results indicate that the formation mechanisms and sources of secondary inorganic species could be different during the two seasons. $\mathrm{BC}$ contributed similar fractions to $\mathrm{PM}_{2.5}$ in both seasons, which are $7 \%-8 \%$, and chloride was generally small at less than $2 \%$. We noticed that the average composition in spring was similar to that observed at a receptor site (Changdao island) in the north coast of Shandong province in spring 2011 (Hu et al., 2013). These results might suggest that aerosol composition did not change significantly, although the PM levels decreased substantially during the last decade. We further compared aerosol composition during and after the heating season in March, and observed remarkably similar mass concentrations and aerosol compositions during the two periods. One of the major reasons was that the residents near the steel company were all relocated to other places. As a result, the emissions from residential coal combustion were small. Further support is that the coal combustion OA only accounted for $\sim 5 \%$ to the total OA mass as discussed in Sect. 3.2.

Although the mass concentrations and aerosol compositions were substantially different, the diurnal patterns were overall similar for all aerosol species during the two seasons, indicating that the factors driving the diurnal variations were similar. As shown in Fig. 3, higher mass concentrations at nighttime and in the early morning than in the daytime were observed for most aerosol species. Such diurnal patterns can be explained by the rising boundary layer height during daytime and the prevailing winds from the east and southeast that brought relatively clean air from the ocean. In contrast, sulfate presented similar and relatively flat diurnal patterns in both fall and spring, consistent with the fact that sulfate was mainly formed over a regional scale. Despite the rising boundary layer height, the sulfate concentrations remained relatively high during daytime. One reason was likely due to the sea-land breeze that brought the potentially high sulfate concentrations over the Yellow Sea (Li et al., 2018) to the sampling site. Organics in fall also showed a relatively flat diurnal pattern due to the dominance of MO-OOA that was highly correlated with sulfate.

\subsection{OA composition and sources}

The mass spectra, time series, and diurnal variations of $\mathrm{OA}$ factors in fall and spring are shown in Figs. 4 and 5. The mass spectra of HOA in both seasons resembled those of primary emissions reported previously (Canagaratna et al., 2004; Lanz et al., 2007; Mohr et al., 2009), showing the typical characteristics of hydrocarbon ion series of $\mathrm{C}_{n} \mathrm{H}_{2 n-1}^{+}$ and $\mathrm{C}_{n} \mathrm{H}_{2 n+1}^{+}$. However, the HOA spectra showed generally higher $f_{44}$ compared with previous studies (14\% in spring and $6 \%$ in autumn) due to the increased thermal decompo- 
(a)

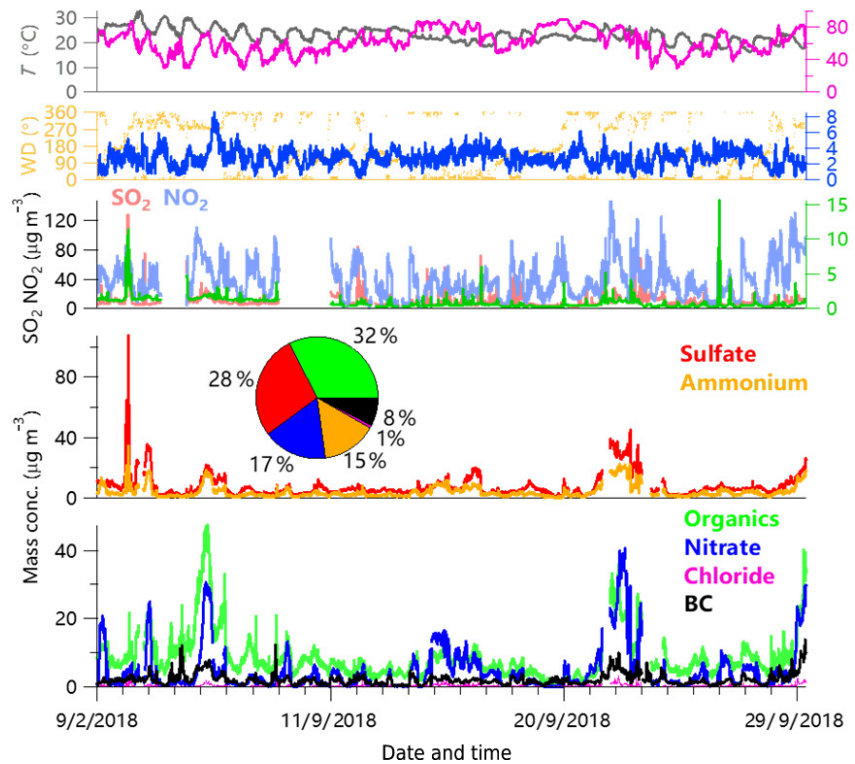

(b)
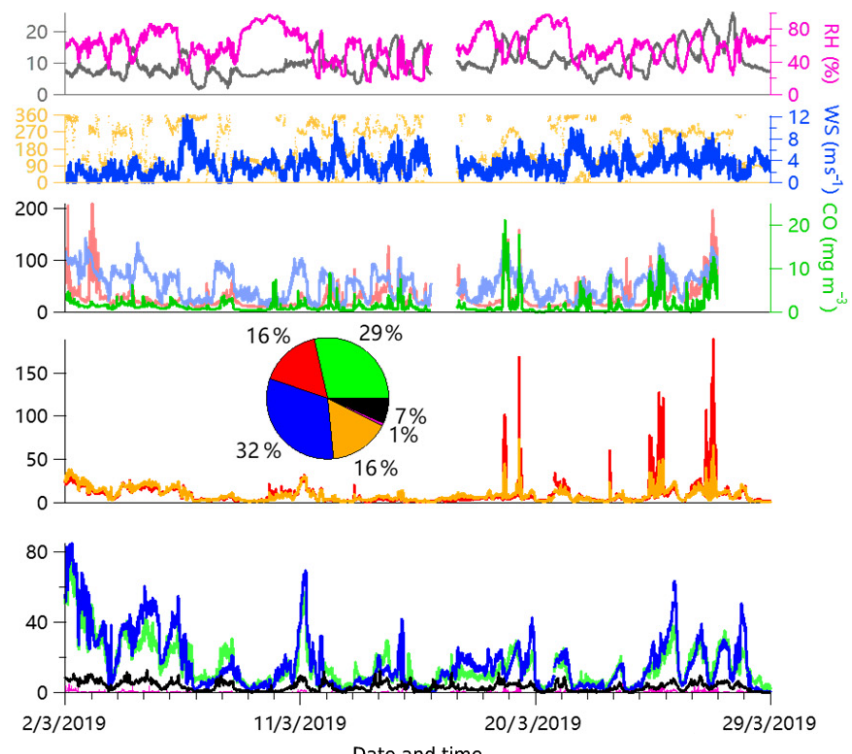

Figure 2. Time series of meteorological variables including $T$, RH, WD, and WS; mass concentrations of gaseous species including $\mathrm{SO}_{2}$, $\mathrm{NO}_{2}$, and $\mathrm{CO}$; and chemical species in $\mathrm{PM}_{2.5}$ in (a) September 2018 and (b) March 2019, respectively. The pie charts show the average chemical composition for the entire campaign.
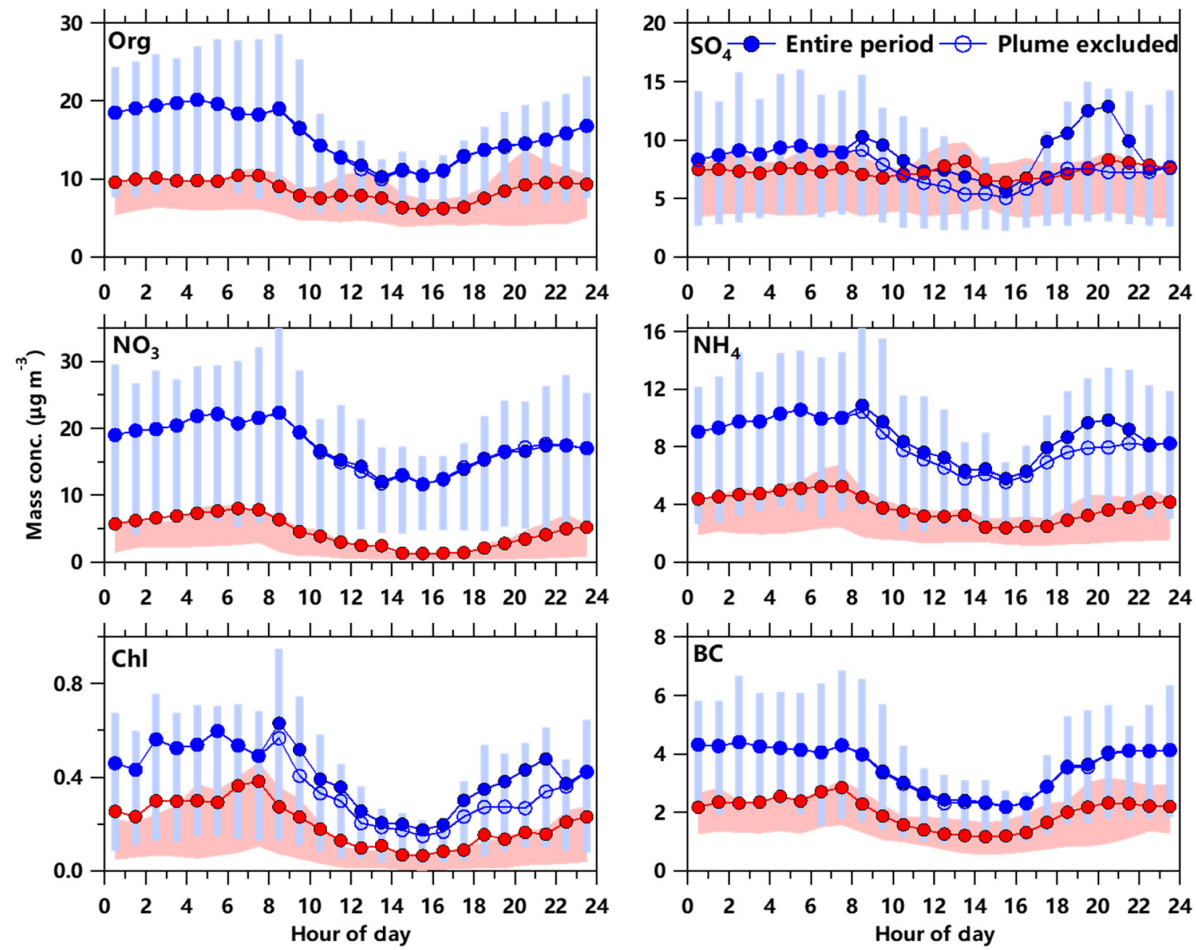

Figure 3. Average diurnal variations in mass concentrations of chemical species in $\mathrm{PM}_{2.5}$ in September 2018 (red) and March 2019 (blue), respectively. The shaded areas and error bars indicate 25 th and 75 th percentiles. Also, the diurnal cycles of aerosol species, by excluding the periods with the influences from steel plants in March, are shown as blue open circles. 
sition in CV. Indeed, Hu et al. (2018b) also observed much higher $f_{44}$ in the HOA spectrum from $\mathrm{CV}$ than that from SV. HOA was well correlated with $\mathrm{NO}_{x}\left(r^{2}=0.52-0.65\right)$ and $\mathrm{BC}\left(r^{2}=0.66-0.75\right)$ in both fall and spring, supporting that HOA was mainly from traffic emissions. This is further supported by the pronounced diurnal cycles of HOA showing higher mass concentrations during morning and evening rush hours. The average mass concentration of HOA was 0.7 and $1.3 \mu \mathrm{g} \mathrm{m}^{-3}$ in September and March, respectively. Although the mass concentration had a difference by a factor of 2 during the two seasons, the HOA contribution to total OA was comparable ( $8 \%$ vs. $9 \%$ ), which is also close to that $\sim 10 \%$ reported in Beijing (Zhang et al., 2014; Hu et al., 2016b; Sun et al., 2016).

A coal combustion OA factor was identified in March 2019 (Fig. 4b and c). The CCOA spectrum showed some similarities to that of HOA at small $\mathrm{m} / \mathrm{z}$ 's, yet it was featured by pronounced PAH-related $\mathrm{m} / z$ 's such as $m / z$ 91, 115, 152, 165, 178, etc. (Dzepina et al., 2007). Despite the high thermal decomposition in $\mathrm{CV}$, the PAH signatures can be well retained as those in previous studies (Sun et al., 2016; Hu et al., 2013, 2016b). In fact, CCOA was highly correlated with these PAH-related $m / z$ 's. For instance, CCOA was tightly correlated with $\mathrm{m} / z 115$ (mainly $\mathrm{C}_{9} \mathrm{H}_{7}^{+}, r^{2}=0.76$ ). Compared with $\mathrm{HOA}$, CCOA presented a higher mass fraction of larger $m / z$ 's $(>120)$, indicating that coal combustion can be an important source of high-molecular-weight organic matter during the heating period. CCOA on average accounted for $5 \%$ of the total OA mass in March with an average concentration of $0.8 \mathrm{\mu g} \mathrm{m}^{-3}$. Compared with previously reported CCOA at urban sites, e.g., Beijing $(\sim 20 \%)$ and the receptor site Changdao in Shandong ( 9\%) (Sun et al., 2016; Hu et al., 2013), CCOA in this study seemed not to be an important contributor to $\mathrm{OA}$, although it presented a pronounced diurnal pattern with higher concentration and fraction at night. This is consistent with the fact that local residents were all relocated to other places, and the residential coal combustion emissions could not be significant.

Two secondary organic aerosol (SOA) factors with different oxidation levels were determined in both September 2018 and March 2019. The total SOA (LO-OOA + MO-OOA) correlated well with secondary inorganic components (SIA, i.e., sulfate + nitrate), and the ratios of SOA to SIA were 0.37 and 0.41 in September and March, respectively, which were close to those reported in Beijing (0.36-0.42) (Huang et al., 2010; Sun et al., 2010). The mass spectra of the two SOA factors were both characterized by a prominent $m / z 44$ (mainly $\mathrm{CO}_{2}^{+}$) peak, and the $f_{44}$ in MO-OOA was higher than that in LO-OOA ( $\sim 36 \%$ vs. $\sim 25 \%$ ). Comparatively, $f_{29}$ and $f_{43}$ were notably higher in LO-OOA than MO-OOA, suggesting that MO-OOA was more oxidized than LO-OOA. Indeed, the MO-OOA tracked better with sulfate $\left(r^{2}=0.45-0.71\right)$, while the LO-OOA correlated better with nitrate $\left(r^{2}=0.56-0.60\right)$. The diurnal patterns of MO-OOA and LO-OOA were also different. LO-OOA showed similar and pronounced diurnal variations in both September and March with much higher mass concentration at nighttime than daytime. Such diurnal patterns were very similar to nitrate, suggesting the similar semivolatile properties of LO-OOA and nitrate (Docherty et al., 2011). In contrast, MO-OOA presented relatively flat diurnal cycles that were remarkably similar to those of sulfate, supporting the fact that MO-OOA was highly aged and formed over a regional scale. SOA together accounted for $92 \%$ and $86 \%$ of the total OA mass in September and March, respectively. These results highlight an overwhelming dominance of SOA in OA during both seasons even though our sampling site is located near the steel plants. However, we also found a change in SOA composition from March to September. In particular, MO-OOA showed an $\sim 10 \%$ higher contribution to OA in September than March $(60 \%$ vs. $51 \%$ ), while the fraction of LO-OOA was comparable ( $32 \%$ vs. $34 \%$ ).

\subsection{Potential sources of aerosol species}

Figure 6 shows the bivariate polar plots of aerosol components and gaseous species in September and March. In general, high concentrations near the center area is associated with local sources, while that far away from the center area is indicative of regional transport (Carslaw and Ropkins, 2012). It can be seen that a high concentration of $\mathrm{PM}_{2.5}$ in September was mainly located in the region to the west (Fig. 6a), suggesting that regional transport played the most important role for air pollution in Rizhao. Comparatively, two high potential source regions for $\mathrm{PM}_{2.5}$ were observed in March including local emissions and transport from the southwest region where RSP is located. The source regions were also substantially different for different aerosol species in September and March. As indicated in Fig. 6a, high mass concentrations of sulfate, ammonium, and chloride were mainly located in the southwest region in both September and March, suggesting the large impacts of the emissions from the RSP. High concentration of chloride likely existed mainly in the form of ammonium chloride, considering that sea salt particles cannot be detected efficiently at a vaporizer temperature of $\sim 540^{\circ} \mathrm{C}$. We also observed high potential source regions to the west of the sampling site for sulfate, ammonium, and chloride in September. This result indicated that regional transport from the west, e.g., Linyi, can also be a significant contribution to air pollution in Rizhao. Comparatively, organics and nitrate showed very different sources between September and March. While organics and nitrate were dominantly from regional transport from the west in September, they were mainly from local emissions and production in March. BC showed similar source regions in the two seasons, which were from both local emissions and regional transport.

HOA and LO-OOA showed similar potential source regions to those of organics and nitrate, i.e., mainly trans- 


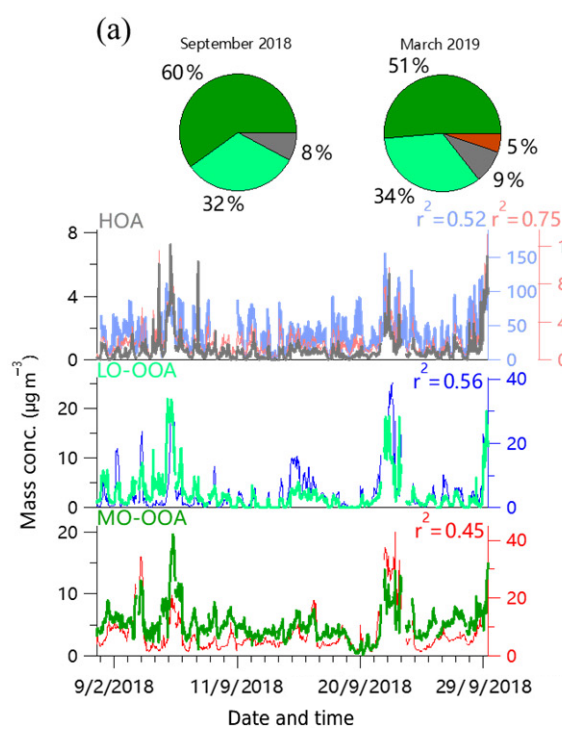

(b)

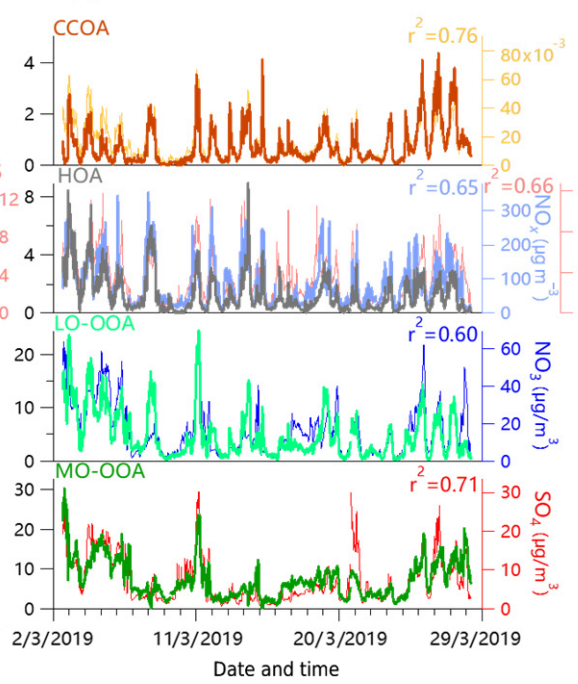

(c)

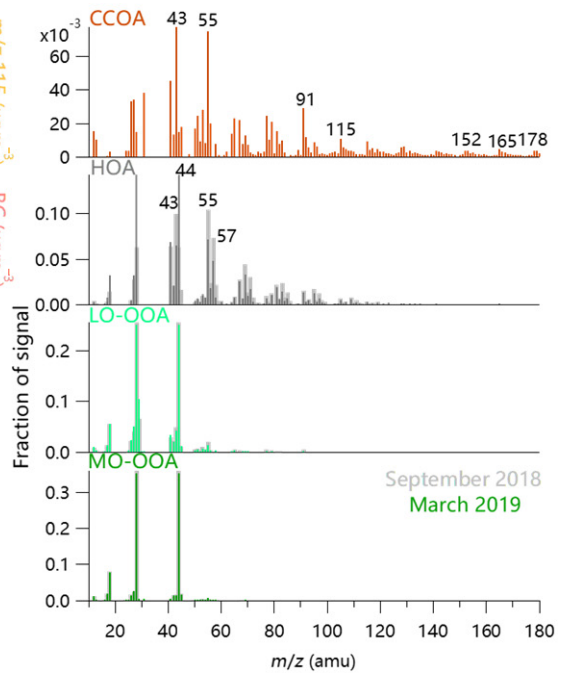

Figure 4. (a, b) Time series and (c) mass spectral profiles of OA factors in September 2018 and March 2019. The time series of external tracer species are also shown for comparisons. The two pie charts present the average OA composition in September and March, respectively. Note that the periods with the influences from steel plants were excluded when performing correlation analysis between $\mathrm{MO}_{-} \mathrm{OOA}$ and $\mathrm{SO}_{4}$ in panels (a) and (b).

(a)

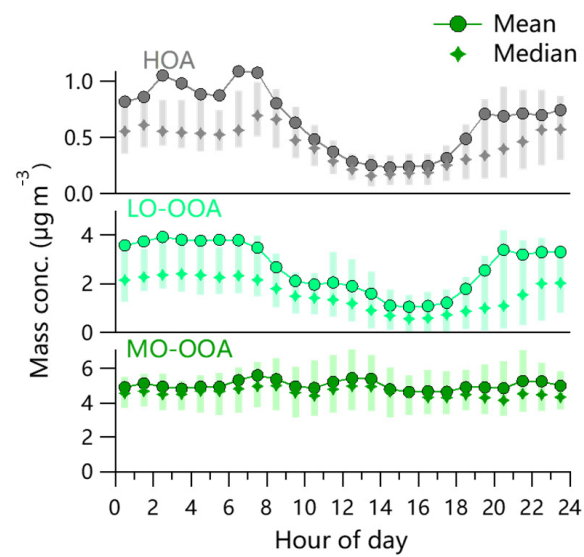

Figure 5. Diurnal variations in mass concentration of OA factors in and 75 th percentiles.

ported from the west in September 2018 with an increased contribution from local emissions in March 2019. In addition, a potential source region located to the northwest was also observed for LO-OOA in March. Similar to HOA and LO-OOA, the major source region of CCOA was located to the west with an additional source region to the southwest. The high potential source regions of MO-OOA were more complicated and have many differences between the two seasons. As shown in Fig. 6b, regional transport played a significant role for the high mass concentrations of MO- (b)

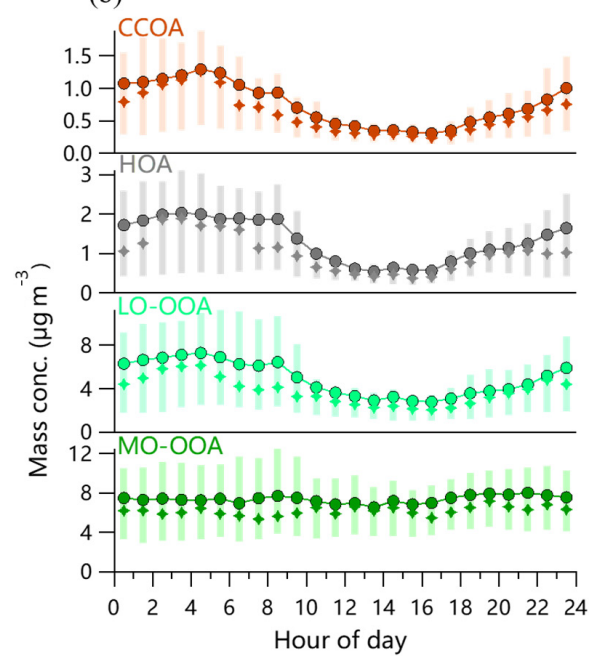

(a) September 2018 and (b) March 2019. The error bars indicate 25th OOA in both September and March. While MO-OOA was mainly transported to the sampling site from the west in fall, the transport from the southwest and northwest also contributed substantially to the high mass loading of MO-OOA in spring, elucidating the diverse sources of MO-OOA during this season. Overall, the regional transport from the west was the most significant and common source for all OA factors in September and March, although that from the northwest and southwest also played a role in spring. The large differences in sources between sulfate, ammonium, and OA 
(a)
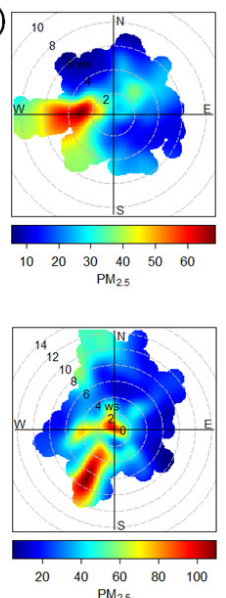

(b)
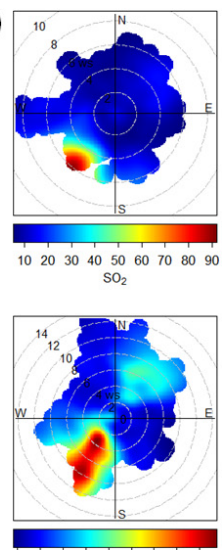

102030405060708090
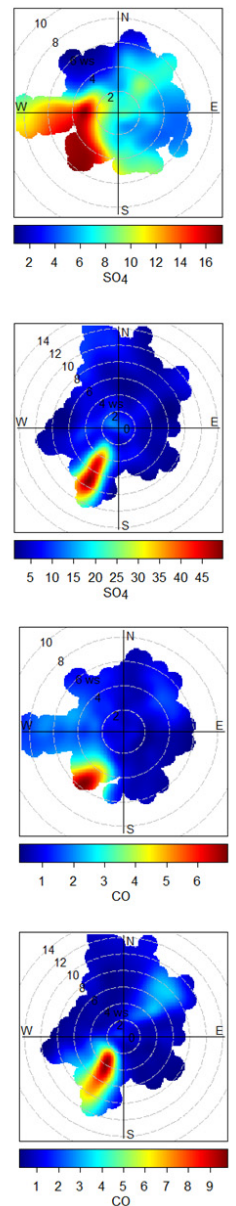
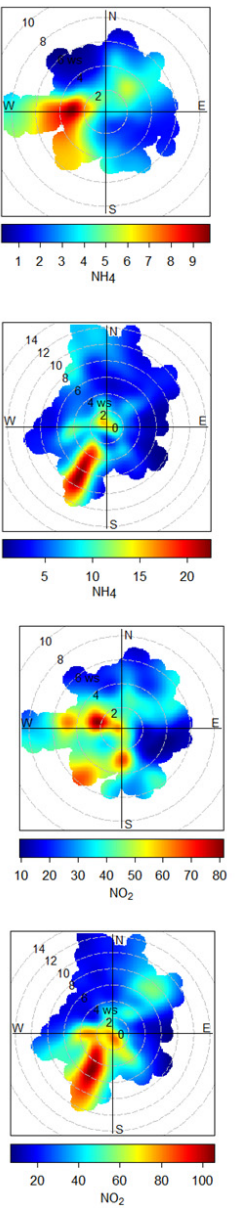
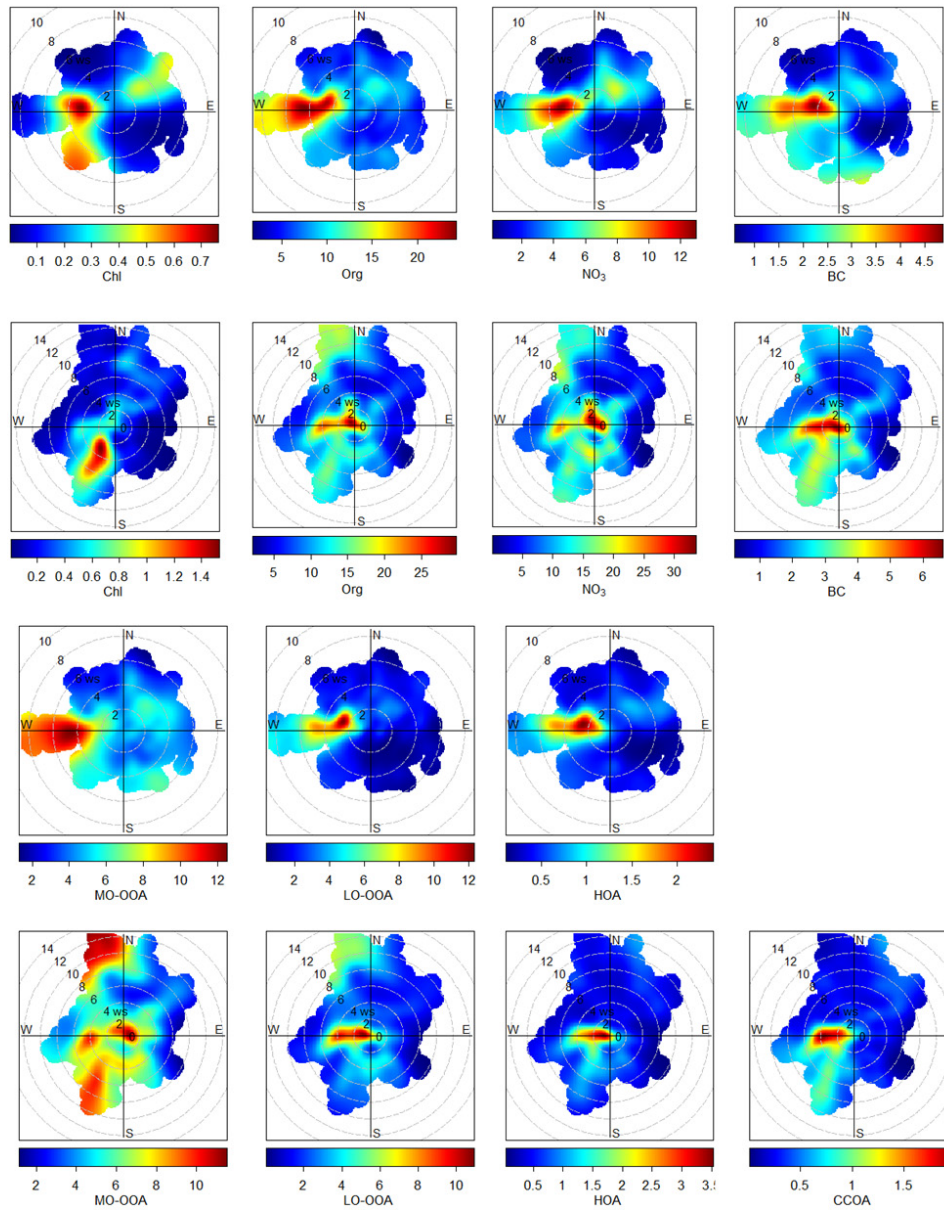

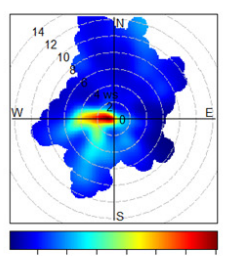

$\begin{array}{llllllll}0.5 & 1 & 1.5 & 2 & 2.5 & 3 & 3 & 3\end{array}$

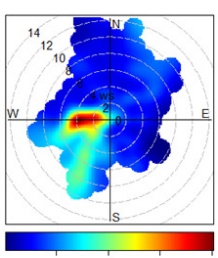

$0.5 \quad 115$

Figure 6. Bivariate polar plots of (a) $\mathrm{PM}_{2.5}$ and aerosol species; (b) $\mathrm{SO}_{2}, \mathrm{CO}, \mathrm{NO}_{2}$, and $\mathrm{OA}$ factors in September 2018 (third row) and March 2019 (fourth row), respectively.

factors in spring also demonstrated that the industrial plumes with high concentrations of ammonium sulfate were not associated with correspondingly high OA.

The potential source regions for high concentrations of $\mathrm{CO}$ and $\mathrm{SO}_{2}$ were located in the southwest region in both September and March, which were also similar to those of sulfate and ammonium. These results illustrated the similar and significant impacts of the emissions from the RSP on $\mathrm{CO}$ an $\mathrm{SO}_{2}$ as those of ammonium sulfate. We also noticed relatively high concentrations of $\mathrm{CO}$ and $\mathrm{SO}_{2}$ in the northeast region in March, suggesting the potential impacts of the SSP. However, the impacts appeared to be much smaller than that of RSP. One reason is that the current steel production of the SSP was much smaller than that of RSP. Another reason could be due to the different FGD (Saarnio et al., 2014) and emission control technologies. Compared with $\mathrm{CO}$ and $\mathrm{SO}_{2}$, $\mathrm{NO}_{2}$ was subject to multiple influences from steel plants, regional transport from the west and south, and local production.

\subsection{Industrial plumes}

Six clear industrial plumes, one in September and five in March, were observed during this study. Depending on meteorological conditions, the duration of plumes lasted from $\sim 2$ to $13 \mathrm{~h}$. As shown in Fig. 7, the steelworks plumes were characterized by dramatic increases in sulfate and ammonium, while the changes in organics and nitrate were small. This result was consistent with a study near a steel plant in Wales (UK), which also showed sharp increases in sulfate and sulfur-containing particles (Dall'Osto and Harrison, 2006). For example, the sulfate concentrations varied significantly during the plume period with the highest concentrations being 108 and $189 \mu^{-3} \mathrm{~m}^{-3}$ in September and March, respectively. By subtracting the background concentration that was determined as the average of $1 \mathrm{~h}$ data before and after the plume, we found that the average mass concentration of $\mathrm{PM}_{2.5}$ emitted from steel plants varied from 18 to $55 \mathrm{~g} \mathrm{~m} \mathrm{~m}^{-3}$ during the six plumes, suggesting a large impact of steel plant emissions on the air quality nearby. Figure 7 shows that aerosol particles from the steel plants were over- 

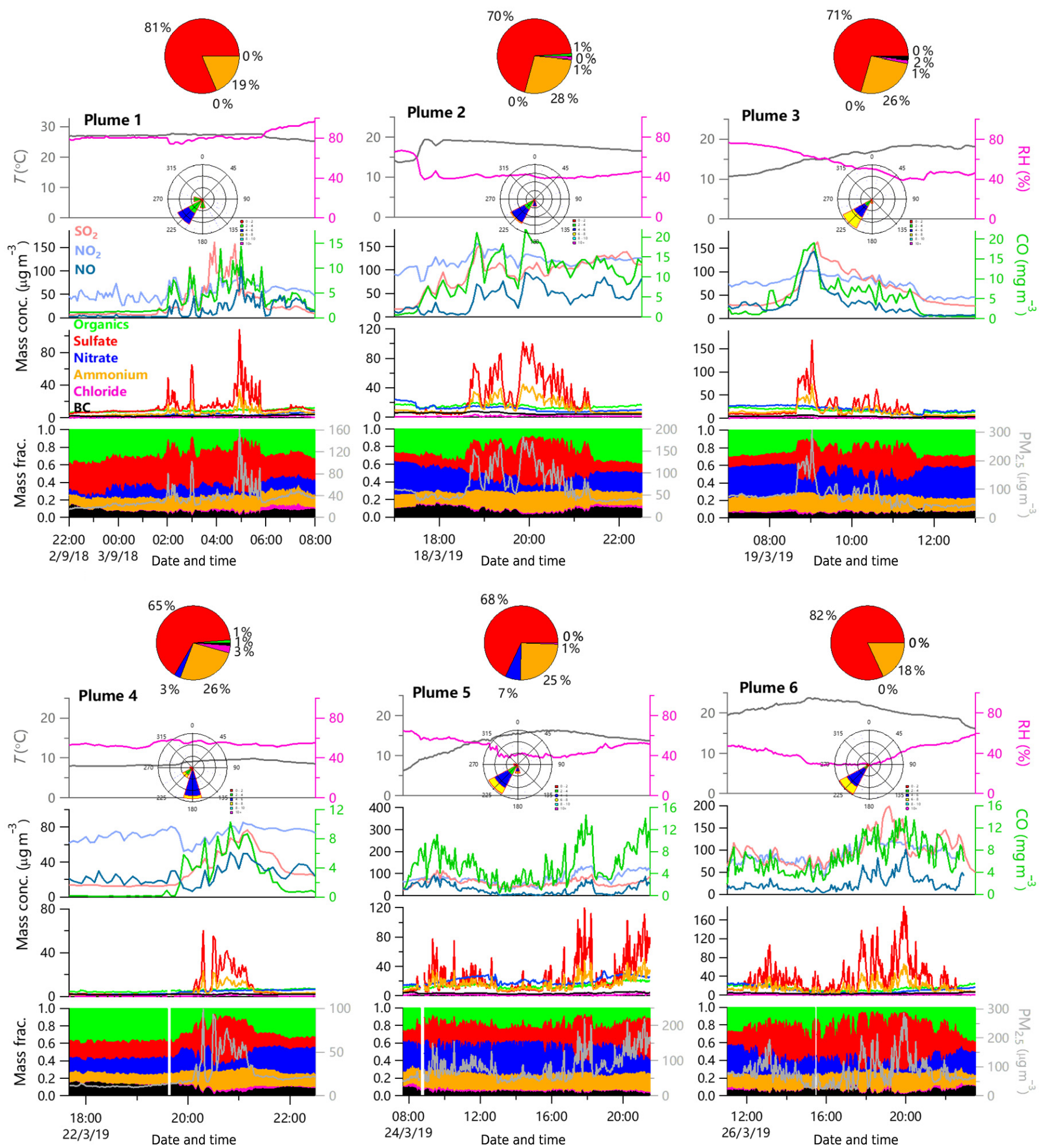

Figure 7. Evolution of meteorological parameters including $T$ and RH, gaseous species, mass concentrations, and mass fractions of chemical species in $\mathrm{PM}_{2.5}$ during six steelworks plume episodes. The pie charts show the contribution of each species emitted completely from steel plants. The wind rose plots depict the prevailing wind direction during each plume period. 

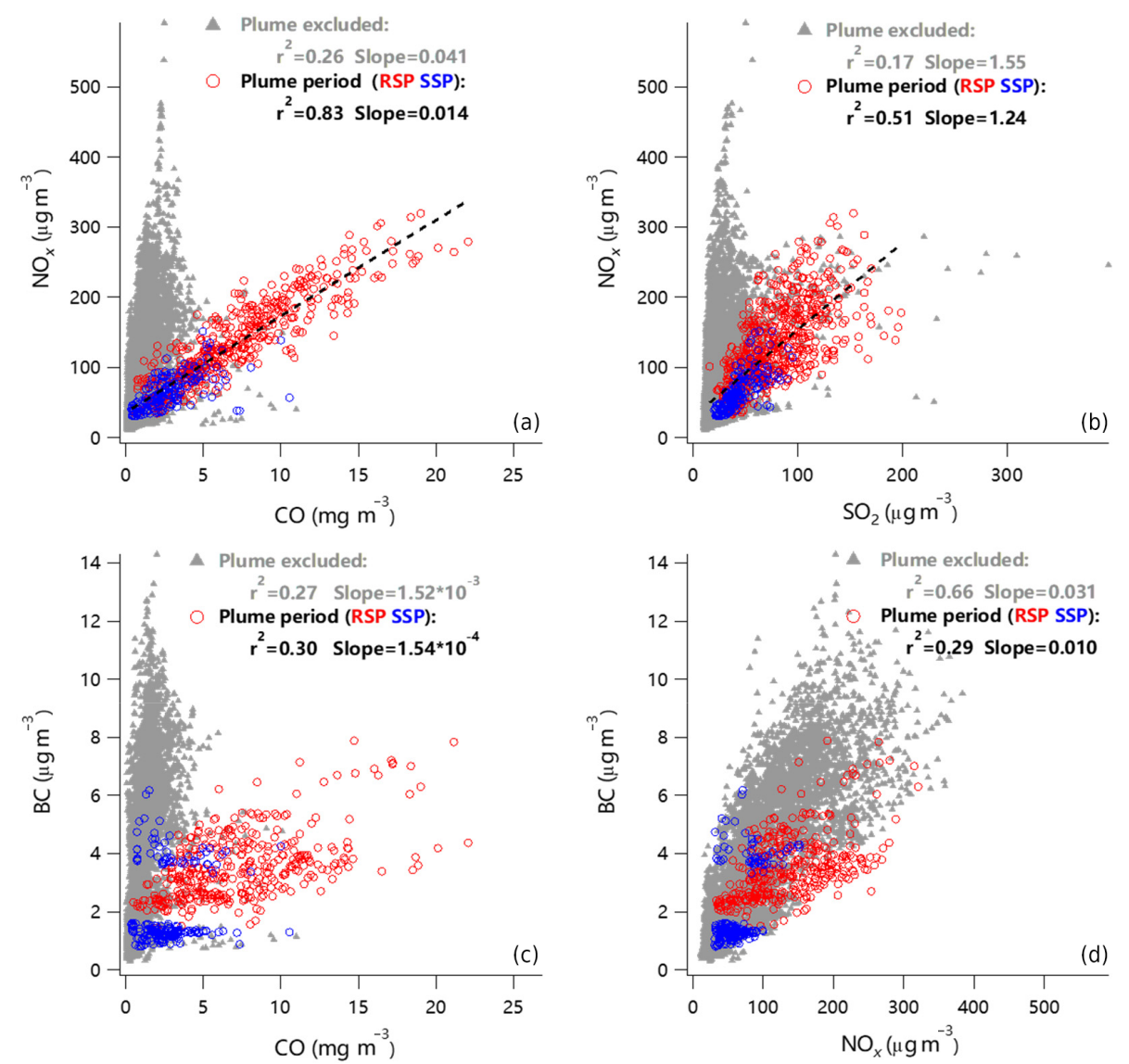

Figure 8. Correlations between (a) $\mathrm{NO}_{x}$ and $\mathrm{CO}$, (b) $\mathrm{NO}_{x}$ and $\mathrm{SO}_{2}$, (c) $\mathrm{BC}$ and $\mathrm{CO}$, and (d) $\mathrm{BC}$ and $\mathrm{NO}_{x}$ during periods with (open circles) and without (gray triangle) influences of the emissions from the steel plants. RSP is the Rizhao steel plant and SSP is the Shandong steel plant.

whelmingly dominated by ammonium sulfate, and the contribution of ammonium bisulfate to the total mass was in the range of $\sim 20 \%-40 \%$. We noticed that the occurrence of six plumes was associated with the southerly and southwesterly winds (Fig. 7), suggesting that ammonium sulfate and bisulfate particles were dominantly from RSP, while the emissions from the SSP appeared to be small. One reason is that more advanced purification and emission control technologies are used for the newly built SSP. Unfortunately, whether ammonium sulfate and bisulfate were directly emitted from the steel plants or from the reactions of $\mathrm{SO}_{3}$ with $\mathrm{NH}_{3}$ during transport from the steel plant to the sampling site is unknown.

We also observed large increases in gaseous species of $\mathrm{CO}$, $\mathrm{SO}_{2}$, and $\mathrm{NO}_{x}$ from steel plants during the plume periods. As shown in Fig. 8, CO was highly correlated with $\mathrm{NO}_{x}$ $\left(r^{2}=0.83\right)$, and $\mathrm{NO}_{x}$ was also moderately correlated with $\mathrm{SO}_{2}\left(r^{2}=0.51\right)$ during the periods of the six plumes, while such correlations were much weaker during periods in the absence of plume influences $\left(r^{2}=0.26-0.17\right)$. These results suggest that a large fraction of $\mathrm{CO}, \mathrm{NO}_{x}$, and $\mathrm{SO}_{2}$ were coemitted from the steel plants, while these gaseous pollutants were subject to multiple influences from different sources during other periods. For example, BC, a tracer for incomplete combustion, was highly correlated with $\mathrm{NO}_{x}$ during periods with small influences from steel plants $\left(r^{2}=0.66\right)$, suggesting that $\mathrm{BC}$ and $\mathrm{NO}_{x}$ were mainly from traffic emissions, because steel plants unlikely emit a large amount of BC. As shown in Fig. 8, the average mass ratios of $\mathrm{NO}_{x} / \mathrm{SO}_{2}$ and $\mathrm{NO}_{x} / \mathrm{CO}$ from the steel plant plumes were significantly lower than those during periods in the absence of plumes (1.24 vs. 1.55 and 0.014 vs. 0.04 , respectively). Although the SSP emits much less ammonium sulfate particles, and gaseous $\mathrm{CO}$ and $\mathrm{NO}_{x}$, we found that the ratios of $\mathrm{NO}_{x} / \mathrm{SO}_{2}$ and $\mathrm{NO}_{x} / \mathrm{CO}$ were similar between these two steel plants. The previously reported values of $\mathrm{NO}_{x} / \mathrm{CO}$ from other emission sources, e.g., biomass burning (0.056-8.33) and on-road motor vehicles (0.04-0.05), were significantly larger than the $\mathrm{NO}_{x} / \mathrm{CO}$ ratio during steel plant plumes in this study (Schürmann et al., 2007; Fujita et al., 2012; Tiwari et al., 2015; Santos et al., 2018). Moreover, the $\mathrm{NO}_{x} / \mathrm{CO}$ ratio during plume-excluded period was close to the values from vehicle emissions (0.04 vs. 0.04-0.05) (Fujita et al., 2012). The lower $\mathrm{NO}_{x} / \mathrm{SO}_{2}$ ratio was found to be characteristic of emissions from coal burning, e.g., in power generation plants or 
steelworks, while higher values were generally attributed to vehicle emissions (Parrish et al., 1991). For example, the $\mathrm{NO}_{x} / \mathrm{SO}_{2}$ value of 1.04 , obtained from the fresh flue-gas plume from a coal-fired power plant when FGD and fabric filter were used (similar to the flue-gas cleaning conditions of RSP), is close to the value of 1.24 during steel plant plumes in this study (Mylläri et al., 2016). In conclusion, our results highlight that $\mathrm{NO}_{x} / \mathrm{SO}_{2}$ and $\mathrm{NO}_{x} / \mathrm{CO}$ ratios combined with a significant increase in ammonium sulfate can be used as good diagnostics for evaluating the impacts of steel plant emissions on air quality in industrial regions and nearby.

\section{Conclusions}

We conducted two campaigns in the vicinity of two steelworks in a coastal city in Shandong, China, using a $\mathrm{PM}_{2.5}$ ToF-ACSM and various colocated instruments to investigate aerosol composition and sources in coastal regions and chemical characteristics of air pollutants from the emissions of steel plants. Our results showed that the mass concentrations of $\mathrm{PM}_{2.5}$ varied greatly in the two seasons, and aerosol composition was also substantially different. The average $\mathrm{PM}_{2.5}$ concentration in March $2019\left(54 \pm 44 \mu \mathrm{g} \mathrm{m}^{-3}\right)$ was approximately twice that in September 2018 (26士 $23 \mu \mathrm{g} \mathrm{m}^{-3}$ ) with nitrate being the largest fraction (32\%) followed by organics (29\%). Comparatively, aerosol composition in September showed a high contribution of sulfate $(28 \%)$ and correspondingly low nitrate $(17 \%)$. PMF analysis showed the dominance of SOA in both March and September $(86 \%$ vs. $92 \%)$. While LO-OOA contributed similarly to OA (32\% vs. $34 \%$ ), MO-OOA in September showed a higher contribution than that in March $(60 \%$ vs. $51 \%)$. Most aerosol species showed similar diurnal variations in the two seasons with higher concentrations during nighttime and lower values at daytime, which were primarily driven by boundary layer dynamics and sea-land breeze. Sulfate and MO-OOA, however, presented relatively flat diurnal patterns, because they were formed over a regional scale. Bivariate polar plots reveal the two major sources of air pollutants in this study, including the regional transport from the west and the impacts of steel plant emissions from the southwest. By analyzing six industrial plumes, we found that the emissions of steel plants were characterized by large increases in sulfate and ammonium, as well as in gaseous species of $\mathrm{CO}$ and $\mathrm{SO}_{2}$. In fact, aerosol particles of the six plumes were overwhelmingly dominated by ammonium sulfate and ammonium bisulfate. Although the SSP appeared to emit low concentrations of sulfate and ammonium, we found that the ratios of $\mathrm{NO}_{x} / \mathrm{CO}$ and $\mathrm{NO}_{x} / \mathrm{SO}_{2}$ were close to those from RSP, and they were both significantly different from those during periods in the absence of industrial plumes. Our results highlight that ammonium sulfate, $\mathrm{NO}_{x} / \mathrm{CO}$, and $\mathrm{NO}_{x} / \mathrm{SO}_{2}$ can be used to evaluate and quantify the impacts of steel plant emissions on air quality in industrial regions and nearby. Also, our results demonstrate a need for the RSP to reduce sulfur emissions using more effective and advanced emission control technologies in the future.

Data availability. The data in this study are available from the authors upon request (sunyele@ mail.iap.ac.cn).

Author contributions. YS and ZW designed the research. LL, CX, $\mathrm{QW}, \mathrm{YC}$, and DW conducted the measurements. LL, YH, WZ, and YS analyzed the data. PF, WH, XP, ZW, DRW, and YS reviewed and commented on the paper. LL and YS wrote the paper.

Competing interests. Douglas R. Worsnop is an employee of Aerodyne Research, Inc. (ARI), which developed the ToF-ACSM utilized in this study.

Financial support. This research has been supported by the National Key Research and Development Program of China (grant nos. 2017YFC0212704 and 2017YFC0209601) and the National Natural Science Foundation of China (grant no. 41711540297).

Review statement. This paper was edited by Alex Lee and reviewed by two anonymous referees.

\section{References}

Aiken, A. C., Salcedo, D., Cubison, M. J., Huffman, J. A., DeCarlo, P. F., Ulbrich, I. M., Docherty, K. S., Sueper, D., Kimmel, J. R., Worsnop, D. R., Trimborn, A., Northway, M., Stone, E. A., Schauer, J. J., Volkamer, R. M., Fortner, E., de Foy, B., Wang, J., Laskin, A., Shutthanandan, V., Zheng, J., Zhang, R., Gaffney, J., Marley, N. A., Paredes-Miranda, G., Arnott, W. P., Molina, L. T., Sosa, G., and Jimenez, J. L.: Mexico City aerosol analysis during MILAGRO using high resolution aerosol mass spectrometry at the urban supersite (T0) - Part 1: Fine particle composition and organic source apportionment, Atmos. Chem. Phys., 9, 6633-6653, https://doi.org/10.5194/acp-9-6633-2009, 2009.

Allan, J. D., Williams, P. I., Morgan, W. T., Martin, C. L., Flynn, M. J., Lee, J., Nemitz, E., Phillips, G. J., Gallagher, M. W., and Coe, H.: Contributions from transport, solid fuel burning and cooking to primary organic aerosols in two UK cities, Atmos. Chem. Phys., 10, 647-668, https://doi.org/10.5194/acp-10-6472010, 2010.

Almeida, S. M., Lage, J., Fernandez, B., Garcia, S., Reis, M. A., and Chaves, P. C.: Chemical characterization of atmospheric particles and source apportionment in the vicinity of a steelmaking industry, Sci. Total Environ., 521-522, 411-420, https://doi.org/10.1016/j.scitotenv.2015.03.112, 2015.

Athanasios, K., Sweetman, A. J., and Jones, K. C.: PAH molecular diagnostic ratios applied to atmospheric sources: a critical evaluation using two decades of source inventory and air con- 
centration data from the UK, Environ. Sci. Technol., 45, 8897, https://doi.org/10.1021/es202277u, 2011.

Brock, C. A., Trainer, M., Ryerson, T. B., Neuman, J. A., Parrish, D. D., Holloway, J. S., Nicks Jr., D. K. N., Frost, G. J., Hübler, G., and Fehsenfeld, F. C.: Particle growth in urban and industrial plumes in Texas, J. Geophys. Res., 108, 107-118, https://doi.org/10.1029/2002jd002746, 2003.

Canagaratna, M. R., Jayne, J. T., Ghertner, D. A., Herndon, S., Shi, Q., Jimenez, J. L., Silva, P. J., Williams, P., Lanni, T., Drewnick, F., Demerjian, K. L., Kolb, C. E., and Worsnop, D. R.: Chase Studies of Particulate Emissions from in-use New York City Vehicles, Aerosol Sci. Tech., 38, 555-573, https://doi.org/10.1080/02786820490465504, 2004.

Cao, G. L., Zhang, X. Y., Gong, S. L., An, X. Q., and Wang, Y. Q.: Emission inventories of primary particles and pollutant gases for China, Chinese Sci. Bull., 56, 781-788, https://doi.org/10.1007/s11434-011-4373-7 2011.

Carslaw, D. C. and Ropkins, K.: openair - An R package for air quality data analysis, Environ. Modell. Softw., 27, 52-61, 2012.

Carslaw, K. S., Boucher, O., Spracklen, D. V., Mann, G. W., Rae, J. G. L., Woodward, S., and Kulmala, M.: A review of natural aerosol interactions and feedbacks within the Earth system, Atmos. Chem. Phys., 10, 1701-1737, https://doi.org/10.5194/acp10-1701-2010, 2010.

Chow, J. C., Watson, J. G., Lowenthal, D. H., Chen, L. W. A., and Motallebi, N.: $\mathrm{PM}_{2.5}$ source profiles for black and organic carbon emission inventories, Atmos. Environ., 45, 5407-5414, https://doi.org/10.1016/j.atmosenv.2011.07.011, 2011.

Dall'Osto, M. and Harrison, R.: Chemical characterisation of single airborne particles in Athens (Greece) by ATOFMS, Atmos. Environ., 40, 7614-7631, https://doi.org/10.1016/j.atmosenv.2006.06.053, 2006.

Dall'Osto, M., Booth, M. J., Smith, W., Fisher, R., and Harrison, R. M.: A Study of the Size Distributions and the Chemical Characterization of Airborne Particles in the Vicinity of a Large Integrated Steelworks, Aerosol Sci. Tech., 42, 981-991, https://doi.org/10.1080/02786820802339587, 2008.

Davidson, C. I., Phalen, R. F., and Solomon, P. A.: Airborne Particulate Matter and Human Health: A Review, Aerosol Sci. Tech., 39, 737-749, https://doi.org/10.1080/02786820500191348, 2005.

Docherty, K. S., Aiken, A. C., Huffman, J. A., Ulbrich, I. M., DeCarlo, P. F., Sueper, D., Worsnop, D. R., Snyder, D. C., Peltier, R. E., Weber, R. J., Grover, B. D., Eatough, D. J., Williams, B. J., Goldstein, A. H., Ziemann, P. J., and Jimenez, J. L.: The 2005 Study of Organic Aerosols at Riverside (SOAR-1): instrumental intercomparisons and fine particle composition, Atmos. Chem. Phys., 11, 12387-12420, https://doi.org/10.5194/acp-11-123872011, 2011.

Dzepina, K., Arey, J., Marr, L. C., Worsnop, D. R., Salcedo, D., Zhang, Q., Onasch, T. B., Molina, L. T., Molina, M. J., and Jimenez, J. L.: Detection of particle-phase polycyclic aromatic hydrocarbons in Mexico City using an aerosol mass spectrometer, Int. J. Mass Spectrom., 263, 152-170, https://doi.org/10.1016/j.ijms.2007.01.010, 2007.

Fröhlich, R., Cubison, M. J., Slowik, J. G., Bukowiecki, N., Prévôt, A. S. H., Baltensperger, U., Schneider, J., Kimmel, J. R., Gonin, M., Rohner, U., Worsnop, D. R., and Jayne, J. T.: The ToF-ACSM: a portable aerosol chemical speciation monitor with TOFMS detection, Atmos. Meas. Tech., 6, 3225-3241, https://doi.org/10.5194/amt-6-3225-2013, 2013.

Fujita, E. M., Croes, B. E., Bennett, C. L., Lawson, D. R., Lurmann, F. W., and Main, H. H.: Comparison of Emission Inventory and Ambient Concentration Ratios of CO, NMOG, and $\mathrm{NO}_{x}$ in California's South Coast Air Basin, J. Air Waste Manage., 42, 264 276, https://doi.org/10.1080/10473289.1992.10466989, 2012.

Hu, W., Campuzano-Jost, P., Day, D. A., Croteau, P., Canagaratna, M. R., Jayne, J. T., Worsnop, D. R., and Jimenez, J. L.: Evaluation of the new capture vaporizer for aerosol mass spectrometers (AMS) through field studies of inorganic species, Aerosol Sci. Tech., 51, 735-754, https://doi.org/10.1080/02786826.2017.1296104, 2016a.

Hu, W., Hu, M., Hu, W., Jimenez, J. L., Yuan, B., Chen, W., Wang, M., Wu, Y., Chen, C., Wang, Z., Peng, J., Zeng, L., and Shao, M.: Chemical composition, sources, and aging process of submicron aerosols in Beijing: Contrast between summer and winter, J. Geophys. Res.-Atmos., 121, 1955-1977, https://doi.org/10.1002/2015jd024020, 2016b.

Hu, W., Day, D. A., Campuzanojost, P., Nault, B. A., Park, T., Lee, T., Croteau, P., Canagaratna, M. R., Jayne, J. T., and Worsnop, D. R.: Evaluation of the new capture vaporizer for aerosol mass spectrometers: Characterization of organic aerosol mass spectra, Aerosol Sci. Tech., 52, 1-44, https://doi.org/10.1080/02786826.2018.1454584, 2018a.

Hu, W., Day, D. A., Campuzanojost, P., Nault, B. A., Park, T., Lee, T., Croteau, P., Canagaratna, M. R., Jayne, J. T., and Worsnop, D. R.: Evaluation of the New Capture Vaporizer for Aerosol Mass Spectrometers (AMS): Elemental Composition and Source Apportionment of Organic Aerosols (OA), ACS Earth Space Chem., 2, 410-421, https://doi.org/10.1021/acsearthspacechem.8b00002, $2018 \mathrm{~b}$.

Hu, W. W., Hu, M., Yuan, B., Jimenez, J. L., Tang, Q., Peng, J. F., Hu, W., Shao, M., Wang, M., Zeng, L. M., Wu, Y. S., Gong, Z. H., Huang, X. F., and He, L. Y.: Insights on organic aerosol aging and the influence of coal combustion at a regional receptor site of central eastern China, Atmos. Chem. Phys., 13, 10095-10112, https://doi.org/10.5194/acp-13-10095-2013, 2013.

Huang, R.-J., Zhang, Y., Carlo, B., Kin-Fai, H., Jun-Ji, C., Yongming, H., Daellenbach, K. R., Slowik, J. G., Platt, S. M., and Francesco, C.: High secondary aerosol contribution to particulate pollution during haze events in China, Nature, 514, 218-222, https://doi.org/10.1038/nature13774, 2014.

Huang, X.-F., He, L.-Y., Hu, M., Canagaratna, M. R., Sun, Y., Zhang, Q., Zhu, T., Xue, L., Zeng, L.-W., Liu, X.-G., Zhang, Y.-H., Jayne, J. T., Ng, N. L., and Worsnop, D. R.: Highly time-resolved chemical characterization of atmospheric submicron particles during 2008 Beijing Olympic Games using an Aerodyne High-Resolution Aerosol Mass Spectrometer, Atmos. Chem. Phys., 10, 8933-8945, https://doi.org/10.5194/acp-108933-2010, 2010.

Jinhuan, Q. and Liquan, Y.: Variation characteristics of atmospheric aerosol optical depths and visibility in North China during 1980-1994, Atmos. Environ., 34, 603-609, https://doi.org/10.1016/s1352-2310(99)00173-9 2000.

Laden, F., Neas, L. M., Dockery, D. W., and Schwartz, J.: Association of Fine Particulate Matter from Different Sources with Daily Mortality in Six U.S. Cities, Environ. Health. Persp., 108, 941-947, https://doi.org/10.1289/ehp.00108941, 2000. 
Lage, J., Almeida, S. M., Reis, M. A., Chaves, P. C., Ribeiro, T., Garcia, S., Faria, J. P., Fernandez, B. G., and Wolterbeek, H. T.: Levels and spatial distribution of airborne chemical elements in a heavy industrial area located in the north of Spain, J. Toxicol. Env. Heal. A, 77, 856-866, https://doi.org/10.1080/15287394.2014.910156, 2014.

Lanz, V. A., Alfarra, M. R., Baltensperger, U., Buchmann, B., Hueglin, C., and Prévôt, A. S. H.: Source apportionment of submicron organic aerosols at an urban site by factor analytical modelling of aerosol mass spectra, Atmos. Chem. Phys., 7, 15031522, https://doi.org/10.5194/acp-7-1503-2007, 2007.

Leoni, C., Hovorka, J., Docekalova, V., Cajthaml, T., and Marvanova, S.: Source Impact Determination using Airborne and Ground Measurements of Industrial Plumes, Environ. Sci. Technol., 50, 9881, https://doi.org/10.1021/acs.est.6b02304, 2016.

Li, J., Chen, X., Wang, Z., Du, H., Yang, W., Sun, Y., Hu, B., Li, J., Wang, W., Wang, T., Fu, P., and Huang, H.: Radiative and heterogeneous chemical effects of aerosols on ozone and inorganic aerosols over East Asia, Sci. Total Environ., 622-623, 13271342, https://doi.org/10.1016/j.scitotenv.2017.12.041, 2018.

Li, Y. J., Sun, Y., Zhang, Q., Li, X., Li, M., Zhou, Z., and Chan, C. K.: Real-time chemical characterization of atmospheric particulate matter in China: A review, Atmos. Environ., 158, 270-304, https://doi.org/10.1016/j.atmosenv.2017.02.027, 2017.

Lohmann, U. and Feichter, J.: Global indirect aerosol effects: a review, Atmos. Chem. Phys., 5, 715-737, https://doi.org/10.5194/acp-5-715-2005, 2005.

Mohr, C., Huffman, J. A., and Cubison, M. J.: Characterization of Primary Organic Aerosol Emissions from Meat Cooking, Trash Burning, and Motor Vehicles with High-Resolution Aerosol Mass Spectrometry and Comparison with Ambient and Chamber Observations, Environ. Sci. Technol., 43, 2443-2449, https://doi.org/10.1021/es8011518, 2009.

Mylläri, F., Asmi, E., Anttila, T., Saukko, E., Vakkari, V., Pirjola, L., Hillamo, R., Laurila, T., Häyrinen, A., Rautiainen, J., Lihavainen, H., O'Connor, E., Niemelä, V., Keskinen, J., Dal Maso, M., and Rönkkö, T.: New particle formation in the fresh flue-gas plume from a coal-fired power plant: effect of flue-gas cleaning, Atmos. Chem. Phys., 16, 7485-7496, https://doi.org/10.5194/acp16-7485-2016, 2016.

Ng, N. L., Canagaratna, M. R., and Jimenez, J. L.: Real-Time Methods for Estimating Organic Component Mass Concentrations from Aerosol Mass Spectrometer Data, Environ. Sci. Technol., 45, 910-916, https://doi.org/10.1021/es102951k, 2011a.

Ng, N. L., Herndon, S. C., Trimborn, A., Canagaratna, M. R., Croteau, P. L., Onasch, T. B., Sueper, D., Worsnop, D. R., Zhang, Q., Sun, Y. L., and Jayne, J. T.: An Aerosol Chemical Speciation Monitor (ACSM) for Routine Monitoring of the Composition and Mass Concentrations of Ambient Aerosol, Aerosol Sci. Tech., 45, 780-794, https://doi.org/10.1080/02786826.2011.560211, 2011b.

Osornio-Vargas, A. R., Bonner, J. C., Ernesto, A. M., Leticia, M., Claudia, G. C., Sergio, P. D. L. R., Javier, M., and Irma, R.: Proinflammatory and cytotoxic effects of Mexico City air pollution particulate matter in vitro are dependent on particle size and composition, Environ. Health. Persp., 111, 1289-1293, https://doi.org/10.1289/ehp.5913 2003.

Paatero, P. and Tapper, U.: Positive matrix factorization: A non-negative factor model with optimal utilization of er- ror estimates of data values, Environmetrics, 5, 111-126, https://doi.org/10.1002/env.31700502032010.

Parrish, D. D., Trainer, M., Buhr, M. P., Watkins, B. A., and Fehsenfeld, F. C.: Carbon monoxide concentrations and their relation to concentrations of total reactive oxidized nitrogen at two rural U.S. sites, J. Geophys. Res., 96, 9309-9320, https://doi.org/10.1029/91JD00047, 1991.

Pope III, C. A., Burnett, R. T., Thun, M. J., Calle, E. E., Krewski, D., Ito, K., and Thurston, G. D.: Lung Cancer, Cardiopulmonary Mortality, and Long-term Exposure to Fine Particulate Air Pollution, JAMA, 287, 1132-1141, https://doi.org/10.1001/jama.287.9.1132, 2002.

Reddy, M. and Venkataraman, C.: Atmospheric optical and radiative effects of anthropogenic aerosol constituents from India, Atmos. Environ., 34, 4511-4523, https://doi.org/10.1016/S13522310(00)00105-9, 2000.

Saarnio, K., Frey, A., Niemi, J. V., Timonen, H., Rönkkö, T., Karjalainen, P., Vestenius, M., Teinilä, K., Pirjola, L., and Niemelä, V.: Chemical composition and size of particles in emissions of a coal-fired power plant with flue gas desulfurization, J. Aerosol. Sci., 73, 14-26, https://doi.org/10.1016/j.jaerosci.2014.03.004, 2014.

Santos, F., Longo, K., Guenther, A., Kim, S., Gu, D., Oram, D., Forster, G., Lee, J., Hopkins, J., Brito, J., and Freitas, S.: Biomass burning emission disturbances of isoprene oxidation in a tropical forest, Atmos. Chem. Phys., 18, 12715-12734, https://doi.org/10.5194/acp-18-12715-2018, 2018.

Schürmann, G., Schäfer, K., Jahn, C., Hoffmann, H., Bauerfeind, M., Fleuti, E., and Rappenglück, B.: The impact of $\mathrm{NO}_{x}, \mathrm{CO}$ and $\mathrm{VOC}$ emissions on the air quality of Zurich airport, Atmos. Environ., 41, 103-118, https://doi.org/10.1016/j.atmosenv.2006.07.030, 2007.

Setyan, A. and Jing, W.: Very low emissions of airborne particulate pollutants measured from two municipal solid waste incineration plants in Switzerland, Atmos. Environ., 166, 99-109, https://doi.org/10.1016/j.atmosenv.2017.07.018, 2017.

Setyan, A., Flament, P., Locoge, N., Deboudt, K., Riffault, V., Alleman, L. Y., Schoemaecker, C., Arndt, J., Augustin, P., Healy, R. M., Wenger, J. C., Cazier, F., Delbarre, H., Dewaele, D., Dewalle, P., Fourmentin, M., Genevray, P., Gengembre, C., Leonardis, T., Marris, H., and Mbengue, S.: Investigation on the near-field evolution of industrial plumes from metalworking activities, Sci. Total Environ., 668, 443-456, https://doi.org/10.1016/j.scitotenv.2019.02.399, 2019.

Sun, J., Zhang, Q., Canagaratna, M. R., Zhang, Y., Ng, N. L., Sun, Y., Jayne, J. T., Zhang, X., Zhang, X., and Worsnop, D. R.: Highly time- and size-resolved characterization of submicron aerosol particles in Beijing using an Aerodyne Aerosol Mass Spectrometer, Atmos. Environ., 44, 131-140, https://doi.org/10.1016/j.atmosenv.2009.03.020, 2010.

Sun, Y., Wang, Z., Dong, H., Yang, T., Jie, L., Pan, X., Ping, C., and Jayne, J. T.: Characterization of summer organic and inorganic aerosols in Beijing, China with an Aerosol Chemical Speciation Monitor, Atmos. Environ., 51, 250-259, https://doi.org/10.1016/j.atmosenv.2012.01.013, 2012.

Sun, Y., Du, W., Fu, P., Wang, Q., Li, J., Ge, X., Zhang, Q., Zhu, C., Ren, L., Xu, W., Zhao, J., Han, T., Worsnop, D. R., and Wang, Z.: Primary and secondary aerosols in Beijing in winter: sources, 
variations and processes, Atmos. Chem. Phys., 16, 8309-8329, https://doi.org/10.5194/acp-16-8309-2016, 2016.

Sun, Y.-L., Zhang, Q., Schwab, J. J., Demerjian, K. L., Chen, W.N., Bae, M.-S., Hung, H.-M., Hogrefe, O., Frank, B., Rattigan, O. V., and Lin, Y.-C.: Characterization of the sources and processes of organic and inorganic aerosols in New York city with a high-resolution time-of-flight aerosol mass apectrometer, Atmos. Chem. Phys., 11, 1581-1602, https://doi.org/10.5194/acp11-1581-2011, 2011.

Taiwo, A. M., Harrison, R. M., and Shi, Z.: A review of receptor modelling of industrially emitted particulate matter, Atmos. Environ., 97, 109-120, https://doi.org/10.1016/j.atmosenv.2014.07.051, 2014.

Tiwari, S., Dahiya, A., and Kumar, N.: Investigation into relationships among $\mathrm{NO}, \mathrm{NO}_{2}, \mathrm{NO}_{x}, \mathrm{O}_{3}$, and $\mathrm{CO}$ at an urban background site in Delhi, India, Atmos. Res., 157, 119-126, https://doi.org/10.1016/j.atmosres.2015.01.008, 2015.

Ulbrich, I. M., Canagaratna, M. R., Zhang, Q., Worsnop, D. R., and Jimenez, J. L.: Interpretation of organic components from Positive Matrix Factorization of aerosol mass spectrometric data, Atmos. Chem. Phys., 9, 2891-2918, https://doi.org/10.5194/acp-92891-2009, 2009.

Weitkamp, E. A., Pancras, L. P. J., Ondov, J. M., Polidori, A., Turpin, B. J., and Robinson, A. L.: Fine particle emission profile for a large coke production facility based on highly timeresolved fence line measurements, Atmos. Environ., 39, 67196733, https://doi.org/10.1016/j.atmosenv.2005.06.028, 2005.
Wong, H. K. T., Banic, C. M., Robert, S., Nejedly, Z., and Campbell, J. L.: In-stack and in-plume characterization of particulate metals emitted from a copper smelter, Geochem.-Explor. Env. A., 6, 131-137, https://doi.org/10.1144/1467-7873/05-083, 2006.

Wu, Y., Ge, X., Wang, J., Shen, Y., Ye, Z., Ge, S., Wu, Y., Yu, H., and Chen, M.: Responses of secondary aerosols to relative humidity and photochemical activities in an industrialized environment during late winter, Atmos. Environ., 193, 66-78, https://doi.org/10.1016/j.atmosenv.2018.09.008, 2018.

Yang, Z., Tang, S., Zhang, Z., Liu, C., and Ge, X.: Characterization of PM10 surrounding a cement plant with integrated facilities for co-processing of hazardous wastes, J. Clean Prod., 186, 831-839, https://doi.org/10.1016/j.jclepro.2018.03.178, 2018.

Zhang, J. K., Sun, Y., Liu, Z. R., Ji, D. S., Hu, B., Liu, Q., and Wang, Y. S.: Characterization of submicron aerosols during a month of serious pollution in Beijing, 2013, Atmos. Chem. Phys., 14, 2887-2903, https://doi.org/10.5194/acp-14-2887-2014, 2014.

Zhang, Q., Jimenez, J. L., Canagaratna, M. R., Ulbrich, I. M., Ng, N. L., Worsnop, D. R., and Sun, Y.: Understanding atmospheric organic aerosols via factor analysis of aerosol mass spectrometry: a review, Anal. Bioanal. Chem., 401, 3045-3067, https://doi.org/10.1007/s00216-011-5355-y, 2011. 